\title{
Comparative Carbohydrate Metabolism and a Proposal for a Phylogenetic Relationship of the Acetic Acid Bacteria
}

\author{
BY J. DE LEY \\ Laboratory for Microbiology, Faculty of Sciences, State University, Ghent, Belgium
}

(Received 10 June 1960)

\begin{abstract}
SUMMARY
The oxidation of 20 carbohydrates and derivatives by 45 strains of acetic acid bacteria, representing most of the known species, was studied and correlated with the enzymic constitution of the organisms. The strains of the mesoxydans group of Frateur and the acetate-oxidizing Gluconobacters oxidized the greatest variety of substrates and contained the most complex enzyme system. The strains investigated could be arranged in two main lines, each one with a stepwise decreasing gradation of oxidative properties. In contrast to the expectations evoked by their names, the strains of the 'oxydans' group had only limited oxidative powers and the 'peroxydans' bacteria even less so. The enzymic mechanism of the catabolism of several carbohydrates was discussed. It is proposed to split the acetic acid bacteria into two biotypes: Gluconobacter oxydans and Acetobacter aceti, and to consider the existing species as varieties within the two main types. An approach to the phylogenetic interpretation of the intermediary carbohydrate catabolism of these bacteria is discussed.
\end{abstract}

\section{INTRODUCTION}

The present classification of bacteria is nearly always a system for grouping together apparently closely related strains and a useful key for the identification of unknown bacteria. The objections against the basis of this system, of which Bergey's Manual of Determinative Bacteriology (1957) is the standard compilation, have been voiced many times (van Niel, 1946, 1953; Skerman, 1949; Winogradsky, 1952 ; Sneath, $1957 a$ ) and need not be repeated here. The status of bacterial classification is still far removed from the situation in the taxonomy of higher plants and animals, for it is no reflexion of bacterial phylogeny. The considerations of van Niel $(1946,1953)$ on this problem and his views on a re-organization of our knowledge of the bacterial world in a natural relationship (adansonian relationship (Adanson, 1763) where morphological, physiological, biochemical, enzymic, ecological, immunological and other properties all have equal value) may open the way to an understanding of its phylogeny. To obtain this goal, a file-index with the complete properties of existing strains would be required, which is a task beyond practical possibilities for most investigators. Nevertheless, a first step in this direction has been made by the analysis with an electrical computing machine of many properties of Chromobacterium (Sneath, $1957 b$; Lysenko \& Sneath, 1959) and of many bacteria from the (British) National Collection of Type Cultures (Sneath \& Cowan, 1958). 
A few years ago we began a study of the comparative carbohydrate biochemistry as a possible basis to show a natural relationship and phylogeny of the species within the group of 'acetic acid bacteria'. These bacteria are well suited for this kind of investigation because their species differentiation is mainly based on their carbohydrate metabolism. In Frateur's system of classification (Frateur, 1950) all the strains are arranged in four groups with the characters summarized in Table 1.

Table 1. Summary of the properties of the four groups of acetic acid bacteria according to Frateur (1950)

\begin{tabular}{|c|c|c|c|c|}
\hline Group & Catalase & $\begin{array}{l}\mathrm{CO}_{2} \text { production } \\
\text { from acetic and } \\
\text { lactic acids }\end{array}$ & $\begin{array}{l}\text { Ketogenesis } \\
\text { (glycerol to } \\
\text { dihydroxyacetone; } \\
\text { mannitol to } \\
\text { fructose; } \\
\text { glucose to } \\
\text { 5-keto-gluconate) }\end{array}$ & $\begin{array}{l}\text { Oxidation of } \\
\text { glucose to } \\
\text { gluconic acid }\end{array}$ \\
\hline Peroxydans & - & + & $\begin{array}{c}- \\
\text { or } \\
\text { very weak }\end{array}$ & - \\
\hline Oxydans & + & + & $\begin{array}{c}\overline{-} \\
\text { or } \\
\text { very weak }\end{array}$ & $\begin{array}{c}+ \\
\stackrel{+}{(- \text { for }} \\
\text { A. ascendens })\end{array}$ \\
\hline Mesoxydans & + & + & + & + \\
\hline Suboxydans & + & - & ++ & ++ \\
\hline
\end{tabular}

Extensive investigations in our laboratory of the enzymic equipment of many strains have revealed that often only a few enzymes are responsible for the oxidative properties of intact organisms and that the interpretation of the Warburg experiments was often surprisingly simple and clear-cut in terms of the enzymic outfit of the organisms. Thus it was invariably found that strains which consumed 0.5 mole $\mathrm{O}_{2} /$ mole glucose, oxidized this substrate quantitatively to gluconate with an oxidosome-linked glucose oxidase or a soluble coenzyme-linked glucose dehydrogenase, or both. (Oxidosomes are oxidase-bearing, ultra-microscopic fragments of the 'ghost' or cytoplasmic membrane (De Ley, 1960).) The same applied to many other substrates (see below). Also, several substrates were oxidized by two pathways, one of them being the hexose monophosphate oxidative cycle (also called Horecker cycle, pentose phosphate cycle or shunt), the other usually a non-phosphorylative mechanism. In many cases the relative importance of these two mechanisms could easily be calculated (see, for example, De Ley \& Schell, 1959a). The study of the oxidative capacities of acetic acid bacteria had thus a considerable advantage over most other bacteria, e.g. the Enterobacteriaceae and others, where the results of Warburg experiments do not allow conclusions about the pathways involved. Resting acetic acid bacteria have been used several times for qualitative studies (Bertho, 1932; Cozic, 1933; Kondo \& Ameyama, 1958) or quantitative studies on oxygen uptake. We reported on Acetobacter peroxydans (De Ley, 1958a), the type species of the 'peroxydans' group, on $A$. aceti (De Ley \& Schell, 1959a) from the 'mesoxydans' group, on Gluconobacter suboxydans (De Ley \& Stouthamer, 1959 ) and on G. liquefaciens (De Ley \& Dochy, $1960 a, b$ ). Several other species were studied by Stouthamer $(1959,1960)$. Yet we felt that the potentialities of this 
method had not been exploited to their full extent. In the present paper we wish to clarify in part this situation by summarizing some of our results with the 45 strains of our collection, which represents most of the known species of acetic acid bacteria. We preferred to use authentic strains which have been described and named by other authors, instead of isolating fresh ones, since the former have often been the origin for the definition of new species, later used in the construction of several systems of classification (Henneberg, 1909; Lafar, 1914; Hermann \& Neuschul, 1931 ; Bergey's Manual, 1957; Frateur, 1950). The recent papers by Shimwell (1959) and Shimwell \& Carr (1959) rejecting the validity of most of the species of the acetic acid bacteria also induced us to submit this report. The fundamental differences between the interpretation of Shimwell and our own on the relationship amongst these bacteria are discussed below.

\section{METHODS}

Organisms. The origin of the strains used are mentioned in Table 2. Upon arrival all the strains were checked for purity by plating on a medium containing $(\mathrm{w} / \mathrm{v})$ $10 \%$ glucose, $3 \% \mathrm{CaCO}_{3}, 1 \%$ yeast extract (Difco) and $2.5 \%$ agar, and were incubated for several days at $30^{\circ}$. Most of the cultures were pure. In some cases mixtures of colony types were seen. From those the strain, corresponding to the name on the label, was isolated. Pure strains were stored on agar slopes of the same medium at $4^{\circ}$ and transferred bi-monthly. The purity of the stock cultures was checked several times a year by plating on several media. Occasionally, the stock cultures were also preserved on beer solidified with $12 \%(\mathrm{w} / \mathrm{v})$ gelatine. These cultures have been used in our laboratory for about 3 years and in most cases no obvious change in their properties was noticed, which is at variance with the results of Shimwell (1957, 1959) and Shimwell \& Carr (1959).

Mass cultures. The bacteria from a 2- or 3-day-old culture on a slope were suspended in sterile $0.01 \mathrm{M}-\mathrm{KH}_{2} \mathrm{PO}_{4}-\mathrm{Na}_{2} \mathrm{HPO}_{4}$ buffer $(\mathrm{pH} \mathrm{6.0})$ and used to inoculate Roux flasks of the same glucose medium as above. In some experiments (see below) other sugars in $5 \%(\mathrm{w} / \mathrm{v})$ concentration were used instead of glucose. The bacteria were grown for 2-3 days at $30^{\circ}$, harvested from the agar surface with $0.01 \mathrm{M}$ of the same buffer ( $\mathrm{pH} 6 \cdot 0$ ) with the aid of a magnetic stirrer, washed at least twice and finally suspended at a concentration of $100 \mathrm{mg}$. (wet wt.) living bacteria/ml. of the same buffer. These suspensions were used at once for the Warburg and other experiments. Acetobacter ascendens, strain A, was unable to grow on glucose; it was therefore grown on beer solidified with $12 \%(\mathrm{w} / \mathrm{v})$ gelatine and incubated at $20^{\circ}$ for 2-3 days.

Warburg experiments. These were carried out in the conventional apparatus at $30^{\circ}$. The main vessel contained 50-100 mg. wet wt. bacteria, suspended in $1.8 \mathrm{ml}$. $0.02 \mathrm{M}$-phosphate buffer ( $\mathrm{pH} \mathrm{6.0)}$ ). The side arm contained $10 \mu$ mole of the substrate in $0.1 \mathrm{ml}$. and the central well $0.1 \mathrm{ml}$. of $20 \%(\mathrm{w} / \mathrm{v}) \mathrm{KOH}$. The oxygen uptake was followed until the reaction was over. When the oxidation was slow, it was followed up to $5 \mathrm{hr}$. The results were corrected for endogenous respiration, which was usually nearly negligible. With some strains the endogenous oxygen uptake remained nearly zero for $2-3 \mathrm{hr}$. and then increased logarithmically to 20 or more $\mu$ mole $\mathrm{O}_{2}$ after $5 \mathrm{hr}$. It appeared to be a spontaneous autolysis of some of the cells, providing oxidizable substrates for the living ones. 
Fermentation experiments. A Kluyver type fermentometer (Kluyver, 1914) was filled with pure mercury. One ml. of a $0.033 \mathrm{M}$-phosphate buffer $(\mathrm{pH} \mathrm{6.0)}$ ) containing 100-500 mg. wet wt. living bacteria and 0.5 mmole glucose was introduced into the upper part of the closed arm and the apparatus incubated at $30^{\circ}$ for at least

Table 2. Origin and specification of the strains, mentioned in this paper

Collection (name under which the organism was received)

$\begin{array}{cc}\text { Strain no. } & \text { Generic name } \\ \text { used in } & \text { used in } \\ \text { this paper } & \text { this paper }\end{array}$

The National Collection of Industrial Bacteria (NCIB), Torry Research Station, Aberdeen Acetobacter aceti (Kützing) Beijerinck

$A$. acetosus (Henneberg) Bergey et al.

8554 Acetobacter

$A$. ascendens (Henneberg) Bergey et al.

2224

4937

$A$. ascendens (Henneberg) Bergey et al.

8168

A. capsulatus Shimwell

A. kuctzingianus (Hansen) Bergey et al.

4943

$A$. melanogenus Beijerinck

3924

A. mesoxydans Frateur

8086

A. mobilis Tosic \& Walker

8622

A. pasteurianus (Hansen) Beijerinck

6428

A. peroxydans Visser 't Hooft

8856

A. rancens Beijerinck

8618

8619

A. suboxydans Kluyver \& de Leeuw

3734

A. turbidans Cosbie, Tosic \& Walker

6424

A. viscosus Shimwell

8181

A. xylinum (Brown) Holland

8747

Bacterium vini acetati Henneberg

4989

Bacterium xylinoides Henneberg

Acetobacter

Acetobacter

Acetobacter

Gluconobacter

Acetobacter

Gluconobacter

Acetobacter

Acetobacter

Acetobacter

Acetobacter

Acetobacter

Gluconobacter

Acetobacter

Gluconobacter

Acetobacter

Acetobacter

4940 Acetobacter

Laboratory for Microbiology, Technological University, Delft, Netherlands
Acetobacter aceti var. muciparus
A. ascendens (Henneberg) Bergey et al.
A. lovaniensis Frateur
A. melanogenus Beijerinck
A. mesoxydans var. saccharovorans
A. paradoxus Frateur
A. pasteurianus (Hansen) Bergey et al.
A. rancens Beijerinck
A. suboxydans Kluyver \& de Leeuw
A. xylinum (Brown) Holland
A. xylinum (Brown) Holland

$\begin{aligned} 5 & \text { Acetobacter } \\ \text { A } & \text { Acetobacter } \\ 13 & \text { Acetobacter } \\ 16 & \text { Gluconobacter } \\ 4 & \text { Acetobacter } \\ 30 & \text { Acetobacter } \\ 11 & \text { Acetobacter } \\ 15 & \text { Acetobacter } \\ 10 & \text { Gluconobacter } \\ 12 & \text { Acetobacter } \\ 25 & \text { Acetobacter }\end{aligned}$

Dr I. Mehlman, Department of Food Technology, University of California, Davis, California,

U.S.A.
Acetobacter rancens Beijerinck (received as $A$. peroxydans)
A. ketogenus
Gluconobacter cerinus var. rosiensis
Acetobacter suboxydans Kluyver \& de Leeuw
A. rancens Beijerinck
'Davis'
$\mathbf{2 4}$
$\mathbf{2 2}$
$\mathbf{2 6}$
$\mathbf{2 3}$
Acetobacter
Acetobacter
Acetobacter
Gluconobacter
Acetobacter
Prof. Asai, Institute for Applied Microbiology, Tokyo, Japan
Gluconobacter liquefaciens Asai
G. cerinus Asai
$\begin{array}{ll}20 & \text { Gluconobacter } \\ 21 & \text { Gluconobacter }\end{array}$

Prof. J. Frateur, Laboratory for Microbiology, the University, Louvain, Belgium Acetobacter aceti (Kützing) Beijerinck

Ch 81

Acetobacter

Dr J. G. Carr, Department of Agriculture and Horticulture, the University, Bristol Acetobacter estunensis Carr

E Acetobacter

Dr A. J. Stouthamer, Laboratory for Microbiology, the University, Utrecht, Netherlands Acetobacter suboxydans Kluyver \& de Leeuw

SU Gluconobacter 
3 days. The amount of gas produced was read every day. Fermentations were also carried out in the Warburg apparatus in a $\mathrm{CO}_{2}$ or $\mathrm{N}_{2}$ atmosphere, with different amounts of glucose or fructose.

The detection of enzymes. As reported in 'Results', this was carried out by the methods described or referred to in previous papers (De Ley, 1954; De Ley \& Verhofstede, 1957; De Ley, 1958a; De Ley \& Schell, 1959a, $b$; De Ley \& Dochy, $1960 a, b$; De Ley \& Defloor, 1959).

\section{RESULTS}

Forty-five strains were studied. The properties of Acetobacter peroxydans, as previously reported (De Ley, 1958 a) were included for comparison. The species names of the strains, as received from the different laboratories, were used unchanged. In accordance with Leifson (1954) we retained the generic name of Acetobacter for the peritrichous or non-flagellated strains of the mesoxydans, oxydans and peroxydans groups of Frateur (1950). For the polarly flagellated bacteria, most of which belong to the suboxydans group of Frateur, we adhered to the name of Gluconobacter, originally proposed by Asai (1934, 1935), for reasons to be mentioned below.

Because the bacteria were nearly always grown on glucose, the shape of the oxidation curves in the Warburg experiments might give an indication about the constitutive or inducible nature of the enzymes concerned in the metabolism of the other substrates.

\section{Metabolism and oxidation of glucose}

All the strains of our collection could be sharply divided into three groups a, $\mathrm{b}$ and $\mathrm{c}$.

Group a. Acetobacter ascendens, strain A, A. paradoxus 30 and the strains of $A$. peroxydans did not attack glucose at all. We detected neither glucose oxidase nor glucose dehydrogenase. For $A$. ascendens, strain $\mathrm{A}$, this explains the original description of Henneberg (1898), who noticed that this species was unable to make acid when growing on glucose media. Other so-called $A$. ascendens strains, e.g. NCIB 4937 and NCIB 8163, oxidized glucose with the uptake of 0.5 or more mole $\mathrm{O}_{2} /$ mole substrate. If we adhere to the definition of Henneberg and to the above results with strain $A$, we cannot include these strains NCIB 4937 and NCIB 8163 in the species ascendens but have to relegate them to another one.

Group $b$. Some strains oxidized glucose only with the uptake of $0.5 \mathrm{~mole} \mathrm{O}_{2} / \mathrm{mole}$ substrate. Here belong Acetobacter rancens 15, 23 and 'Davis', $A$. pasteurianus 11 and 8856, $A$. kützingianus 3924, $A$. rancens var. turbidans 8619 and $A$. ascendens 8163. The other oxidative capacities of these strains were also almost identical. Frateur (1950) redefined the species $A$. rancens; as an additional criterion to his definition we can now add that this species is able to oxidize glucose only to gluconic acid. On the enzymic level this means that $A$. rancens contains only a glucose oxidase and a glucose dehydrogenase or both, but no hexokinase or other mechanism to introduce glucose into the hexose monophosphate oxidative cycle. A. lovaniensis 13 carries out the same reaction with glucose, but is able to grow on ethanol and $\mathrm{NH}_{4}^{+}$as sole carbon and nitrogen source, which differentiates it from $A$. rancens. Both $A$. rancens, as redefined now, and $A$. lovaniensis are unable to use glucose as a carbon source; they grow chiefly at the expense of the yeast extract. The production of gluconate from glucose is an accidental event which has nothing or very little to 
do with the physiological processes involved in the growth of the organisms. The production of gluconate in both species appears to be a useless reaction, which may possibly be regarded as an atavism, a remnant of a metabolic pathway from other acetic acid bacteria, such as the one we unravelled for Gluconobacter suboxydans (De Ley \& Stouthamer, 1959). This interpretation would also explain the results of Hermann \& Neuschul (1931) who found that many strains of acetic acid bacteria, while growing on glucose, converted this substrate nearly quantitatively into gluconate.

Group $c$. All the other strains of the collection oxidized glucose with an uptake of more than 0.5 mole $\mathrm{O}_{2} /$ mole substrate: from 1.2 for Acetobacter estunensis $\mathrm{E}$ to $4.9 \mathrm{O}_{2}$ for $A$. mesoxydans var. saccharovorans 4 . On the whole most strains took up 1-3 mole $\mathrm{O}_{2} /$ mole substrate, which was far below the theoretically expected value of 6. The explanation for this phenomenon was given in a previous paper (De Ley \& Schell, 1959a). Indeed, glucose was metabolized by two independent pathways, which competed for the substrate; one was the oxidation to gluconate and the other the hexokinase, followed by the hexose monophosphate oxidative cycle. If the former mechanism alone was active, an uptake of $0.5 \mathrm{~mole} \mathrm{O}_{2} / \mathrm{mole}$ glucose was expected; with the latter alone, 6 mole $\mathrm{O}_{2} /$ mole glucose. Intermediate $\mathrm{O}_{2}$ uptake between these two extremes allows one to calculate how much of the glucose was oxidized by each pathway. We found (De Ley \& Schell, 1959a) that $A$. aceti $\mathrm{Ch} 31$ converted about $80 \%$ of the glucose into gluconate, the remaining quantity being used as carbon and energy source. This calculation was corroborated by chemical analysis of the end products. By applying similar calculations to the strains of the present paper, which did not oxidize gluconate further, it was found that, for example, $A$. vini acetati 4939 converted $84 \%$ of the glucose to gluconate, $A$. estunensis $\mathrm{E}$ about $87 \%$, etc. The remaining glucose was thus used by way of the hexose monophosphate oxidative cycle, which explains the irisation which occurs when these strains grow on the glucose- $\mathrm{CaCO}_{3}-$ yeast extract-agar medium. For most of the strains of the mesoxydans group and for Gluconobacter, these calculations could not be used, because ketohexonates were also formed.

Efficiency of glucose as a carbon and energy source for growing cells. For most of the strains the yield (wet weight) of organisms/Roux flask was determined. Figure 1 shows that there was a clear correlation between the yield of organisms and their ability in a resting state to oxidize glucose. The higher the $\mathrm{O}_{2}$ uptake/mole substrate (that is the more glucose was consumed via the hexose monophosphate oxidative cycle), the higher the yield of the organisms. Organisms which oxidized glucose only to gluconate grew poorly as compared to the others, and all belonged to the species rancens as redefined above, which also strengthened the former conclusions. Again, this way of interpretating the results applied best to the bacteria of the oxydans group. For the strains of the mesoxydans group and for Gluconobacter, the excess $\mathrm{O}_{2}$ uptake over 0.5 mole $\mathrm{O}_{2}$ did not represent a true measure of the disappearance of glucose by way of the hexose monophosphate oxidative cycle. Yet, as a whole, the same general tendency was observed.

Glycolysis and the fermentation of glucose in the acetic acid bacteria. Neuberg \& Simon $(1928 a, b)$ and Simon (1930) found that Acetobacter ascendens, A. pasteurianus and Gluconobacter suboxydans fermented glucose with the formation of about equal amounts of ethanol and $\mathrm{CO}_{2}$. From a recalculation of their results it may be seen 
that only part of the glucose fermented was accounted for by these end products. The remainder (usually 50-80\%) was apparently converted into unidentified end products. Simon (1930) withdrew the previous results and reported that indeed all of the glucose was accounted for as ethanol $+\mathrm{CO}_{2}$. Why then was glucose not fermented to completion? The answer may be deduced from an experiment of Simon, in which he showed that ethanol appeared to inhibit the fermentation. These authors also described the presence of enzymes of glycolysis in these bacteria. Their conclusion, that acetic acid bacteria contained an active glycolytic mechanism, found its way in the literature (see, for example, Thimann, 1955). In fact, the results of

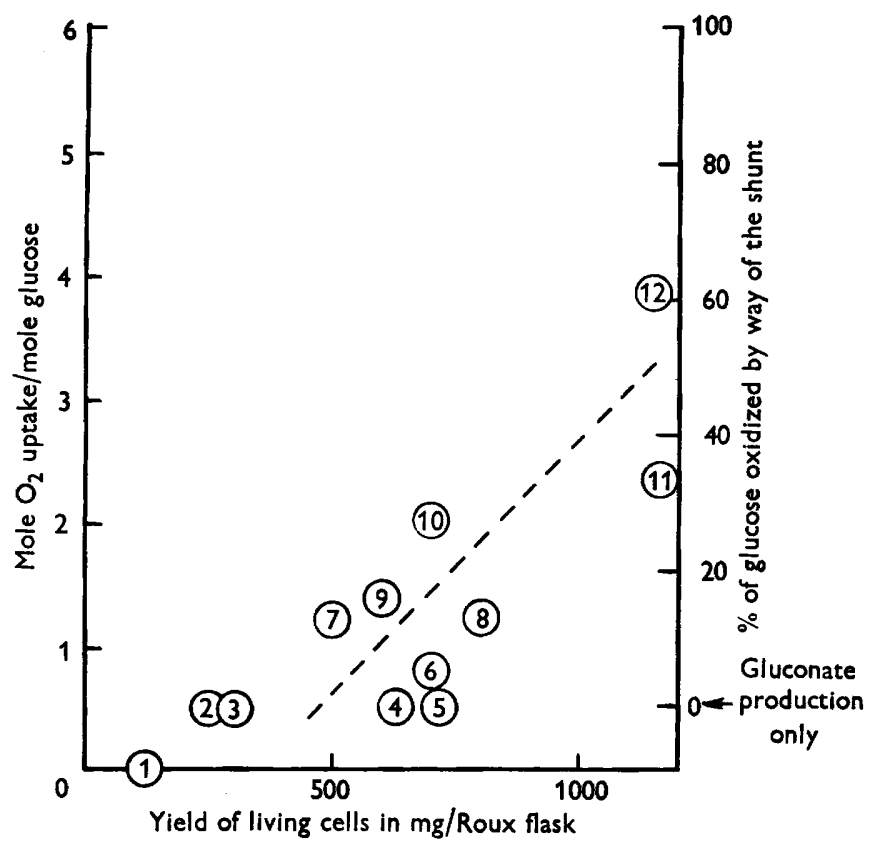

Fig. 1. The relationship between the yield of living cells (wet weight) from the oxydans group after 3 days of growth on the glucose medium in Roux flasks and the final $\mathrm{O}_{2}$ uptake with glucose as a substrate in the Warburg with the same cells in a resting state. Strains used: 1, Acetobacter ascendens A; 2, A. lovaniensis 13; 3, A. kützingianus 3924; $4, A$. pasteurianus $8856 ; 5, A$. pasteurianus $11 ; 6, A$. 'ascendens' 8163 ; $7, A$. estunensis $\mathrm{E}$; 8, A. 'ascendens' 4937; 9, A. vini acetati $4939 ; 10, A$. mobilis 6428; 11, A. turbidans 6424; 12, $A$. acetosus 2224.

Neuberg \& Simon are difficult to understand. Indeed, the typical $A$. ascendens cannot oxidize glucose at all; it contains neither glucose oxidase nor hexokinase. $A$. pasteurianus contains no hexokinase and oxidizes glucose only to gluconate. How then could these strains ferment glucose? A tentative explanation is that the strains used were neither ascendens nor pasteurianus. In the hope of detecting either the unknown end products or the mechanism of glucose fermentation by using labelled substrates, we repeated the experiments of Neuberg \& Simon, but were unable to confirm their results. Most of the strains of our collection were used with the Kluyver fermentometer. In most cases only a trace of gas was formed. The gas production rarely exceeded $10 \%$ of the theoretically expected amount of $\mathrm{CO}_{2}$ 
(22.4 $\mathrm{ml}$.) according to an alcoholic fermentation. At the end of the reaction $1 \mathrm{ml}$. of $20 \%(\mathrm{w} / \mathrm{v}) \mathrm{KOH}$ was introduced and it appeared that only about three-quarters of the gas was $\mathrm{CO}_{2}$. The nature of the residue was not assayed; only about $0.5 \mathrm{ml}$. or less was available. It could not have been due to an air leak, since the gas was always under a slight excess pressure, due to the level of the mercury in the open tube. In some cases more than $10 \%$ of the expected amount of $\mathrm{CO}_{2}$ was formed, but it could invariably be shown that the suspension had become contaminated during storage in the fermentometer, generally with coliform organisms. Neither could gas formation be observed in the anaerobic Warburg experiments, even when they were continued for 5-7 hr. and with varying concentrations of sugar. Prof. J. Frateur kindly informed us (in 1959) that he had been unable to corroborate the results of Neuberg \& Simon. Stouthamer (1960) also found no fermentation with Gluconobacter liquefaciens. Kitos et al. (1958) reported that in G. suboxydans the shunt accounted for the bulk of the oxidation. The general conclusion from all these results appears to be that only a few acetic acid bacteria may contain a very weak glycolytic system, that the claims of Neuberg \& Simon have on the whole not been confirmed, and that it seems desirable to erase this opinion from the literature.

\section{Oxidation of gluconate}

Most of the strains of the oxydans group of Acetobacter were unable to oxidize gluconate. Nearly all the strains of the mesoxydans group and of Gluconobacter attacked this substrate vigorously. Only Acetobacter aceti 8554 and $\mathrm{Ch} 31, A$. aceti var. muciparus 5 and $A$. ketogenus 24 attacked it very weakly.

\section{Oxidation of 2- and 5-ketogluconate}

None of the strains of the oxydans group were able to attack either 2- or 5ketogluconate. In the mesoxydans groups of Acetobacter and in Gluconobacter, the oxidation occurred at random and could not be used for taxonomic purposes. The oxidative abilities for these substrates denoted merely the presence or absence of enzyme systems, described previously (De Ley, 1958 $a$; De Ley \& Defloor, 1959; De Ley \& Stouthamer, 1959), which appeared to be arbitrarily distributed throughout the representatives of the latter groups. It should be stressed, however, that the Warburg method is unable to indicate the presence of weak enzymes. This explains the apparent discrepancy between our results and those of Frateur, Simonart \& Coulon (1954). These authors found by paper chromatography that several strains of the oxydans group were able to form 2-ketogluconate when grown on glucose for up to 30 days. In the Warburg apparatus an uptake of $1 \mu$ mole $\mathrm{O}_{2} / 5 \mathrm{hr} . / 100 \mathrm{mg}$. wet wt. bacteria would surely be regarded as negligible. Yet it can be calculated that this low enzyme activity would be sufficient to allow the production of $2.9 \mathrm{mmole}$ or $617 \mathrm{mg}$. calcium 2-ketogluconate from glucose/month/g. wet wt. bacteria.

\section{The oxidation of mannitol and fructose}

Most strains of the oxydans group of Acetobacter oxidized neither mannitol nor fructose; some strains oxidized both very slowly. Nearly all the strains of the mesoxydans group of Acetobacter and of Gluconobacter oxidized both substrates. Arcus \& Edson (1956) showed a DPN-linked mannitol dehydrogenase in G. suboxydans 
and we found a TPN-specific dehydrogenase in A. aceti Ch 31 (De Ley \& Schell, $1959 a$ ). Fructose, which was formed or excreted outside the cell, became unavailable. We explained this by postulating a fructose permease. Mannitol, which was oxidized to fructose within the cells, was further metabolized. We have encountered similar situations in $G$. viscosus 8131 and $G$. capsulatus 4943. From all the strains investigated from the latter groups, only $A$. mesoxydans 8622 , was unable to oxidize mannitol. It thus appears that the oxidation of mannitol by resting cells might be used as an additional criterion to decide whether a strain belongs in the oxydans or peroxydans groups of Acetobacter (mannitol negative), or belongs in the mesoxydans group of Acetobacter or in Gluconobacter. Fructose oxidation is less suitable for this purpose.

\section{The oxidation of mannose, galactose and pentoses}

Most of the strains investigated were able to oxidize mannose, galactose and pentoses to the corresponding sugar acids. Nearly all the strains except a few representatives of the oxydans group of Acetobacter oxidized mannose with the uptake of 0.5 mole $\mathrm{O}_{2}$ /mole substrate, presumably to mannonic acid. The same is also true for the oxidation of galactose and xylose, from which the corresponding galactonic and xylonic acids were formed. Only Gluconobacter cerinus 21 and G. liquefaciens 20 oxidized galactose with the uptake of 1.0 or more mole $\mathrm{O}_{2} /$ mole substrate, possibly to the 2-ketogalactonate stage or beyond. G. cerinus 21 oxidized xylose with the uptake of $\mathbf{0 . 9 5}$ mole $\mathrm{O}_{2} /$ mole substrate. About half of the strains from the oxydans group of Acetobacter did not attack these substrates. There was a remarkable correlation between the oxidation of both substances: strains which oxidized galactose also converted xylose into xylonic acid and strains which did not attack galactose did not oxidize xylose. This might suggest that the same enzyme was possibly responsible for the oxidation of both substrates.

Ribose and L-arabinose were never oxidized beyond the stage of the corresponding pentonates. We showed previously that all the above substrates are oxidized by oxidases, located on the cytoplasmic membrane (De Ley \& Dochy, $1960 a, b$ ). $D$-Arabinose was not oxidized by any of our strains.

Two main conclusions can be drawn from these results. (i) Mannose, galactose, xylose, L-arabinose and ribose are unsuitable carbon sources for the growth of acetic acid bacteria. On the other hand, these bacteria show excellent promise for the eventual industrial production of these sugar acids. The corresponding enzymes effect an oxidation which has no or very little physiological meaning for the growth of the organisms, which, however, oxidize the substrate when it is present, because they happen to possess the oxidase. The situation is similar to the oxidation of glucose by Acetobacter rancens and $A$. lovaniensis. This possibility was supported by the following experiments. A. turbidans 6424 and $A$. xylinum 12 were grown on a medium containing either $5 \%$ galactose or $5 \%$ xylose, $3 \% \mathrm{CaCO}_{3}, 1 \%$ yeast extract (Difco) and 2.5\% Bacto-agar (Difco). These organisms were harvested and washed as usual. The yields of organisms, when grown on glucose, galactose, or xylose were nearly identical, showing that indeed they did not adapt by growing on the latter two substrates and that they were unable to use them as carbon or energy sources. Furthermore, organisms grown on either of the three substrates oxidized them in the Warburg at the same rate and to the final stage of galactonate and xylonate. (ii) The ubiquitous oxidative capacity for mannose, galactose and 
the pentoses in the mesoxydans group of Acetobacter and in Gluconobacter, and the distribution in the oxydans group of Acetobacter made this a poor taxonomic character.

The oxidation of maltose and saccharose

The ability to oxidize maltose and sucrose was distributed at random over the strains examined. Again the oxydans group of Acetobacter was the poorest. About half of the strains of the mesoxydans group of Acetobacter and of Gluconobacter was able to oxidize either both or one of these substrates. Therefore it seemed appropriate to abolish the varieties 'maltovorans' and 'saccharovorans', as used in the system of Frateur. Lactose and raffinose were not oxidized by any of our strains.

\section{Oxidation of glycerol}

Glycerol was oxidized nearly to completion by all strains tested, except by Acetobacter peroxydans, $A$. ascendens 4937 and hardly by $A$. vini acetati 4939 . It is probably an excellent carbon and energy source. An $\mathrm{O}_{2}$ uptake of at least 2 mole $\mathrm{O}_{2} /$ mole glycerol was quite common. In some cases an induction period was noted, possibly pointing to the formation of an inducible enzyme (glycerokinase) in the enzyme chain.

\section{Oxidation of $i$-erythritol}

i-Erythritol seemed to be very promising for use in classification. None of the strains of the oxydans group of Acetobacter were able to attack it, while all the strains of the mesoxydans group of Acetobacter and of Gluconobacter attacked it. A strain which we had received as $G$. cerinus var. rosiensis 22 appeared to be the only exception. Closer inspection of its properties showed it to be closely related to either $A$. turbidans 6424 or $A$. acetosum 2224 . Very often the oxidation proceeded beyond the erythrulose stage (see Table 3 ). i-Erythritol was oxidized by an oxidase located on the cytoplasmic membrane (De Ley \& Dochy, $1960 a, b$ ).

\section{The oxidation of $\mathrm{D}$-lactate, ethanol and acetate}

All the strains of the oxydans, mesoxydans and peroxydans groups of Acetobacter oxidized D-lactate, ethanol and acetate nearly to completion. We described previously the enzymic mechanism of D-lactate and ethanol oxidation in $A$. peroxydans (De Ley \& Schell, 1959 a). Unpublished experiments carried out with several other species, such as $A$. aceti $\mathrm{Ch} 31, A$. ascendens $\mathrm{A}$, showed that this type of mechanism is a general one in all species investigated. The ability to use D-lactate and ethanol as carbon and energy sources seemed to be the really essential physiological activity for Acetobacter. In several cases an induction period was noticed in the oxidation of acetate. In the polarly flagellate Gluconobacter there appeared to be two distinct groups: (i) G. liquefaciens 20 , which was able to oxidize ethanol, D-lactate and acetate as already pointed out (Asai \& Shoda, 1958; Stouthamer, 1959, 1960; De Ley \& Dochy, 1960); (ii) bacteria such as Gluconobacter suboxydans 26, 10 and SU, G. viscosus 8131, G. capsulatus 4943 and $G$. melanogenus 8086 and 16, which were unable to oxidize acetate and oxidized $D$-lactate and ethanol not beyond acetate. The latter group corresponded to the 'suboxydans' bacteria of Frateur. It may be noted that $G$. cerinus 21 , although it did not oxidize acetate, nevertheless oxidized D-lactate and ethanol nearly to completion. 
Table 3. The oxidation of some carbohydrate derivatives by some representative strains of acetic acid bacteria

Content of the Warburg vessels: see text. The results are expressed as mole $\mathrm{O}_{2}$ uptake per mole substrate at the end of the oxidations. In some cases the reaction was not yet over after $5 \mathrm{hr}$. and is marked by the sign >

$\begin{array}{cccc}\text { Sodium } & \begin{array}{c}\text { Sodium } \\ \text { 2-keto- }\end{array} & \begin{array}{c}\text { Sodium } \\ \text { 5-keto- } \\ \text { gluco- }\end{array} \\ \text { gluco- } & \text { gluco- }\end{array}$

\begin{tabular}{|c|c|c|c|c|c|c|c|c|c|c|c|c|c|c|}
\hline \multicolumn{15}{|c|}{ Peroxydans group } \\
\hline A. peroxydans (8618) & $\mathbf{0}$ & $\mathbf{0}$ & $\mathbf{0}$ & 0 & $\mathbf{0}$ & $\mathbf{0}$ & $\mathbf{0}$ & 0 & $\mathbf{0}$ & 0 & $\mathbf{0}$ & $2 \cdot 7$ & $\mathbf{2 \cdot 6}$ & $1 \cdot 4$ \\
\hline \multicolumn{15}{|c|}{ Oxydans group (22 strains investigated) } \\
\hline A. ascendens (A) & $\mathbf{0}$ & $\mathbf{0}$ & 0 & $\mathbf{0}$ & $\mathbf{0}$ & $\mathbf{0}$ & $\mathbf{0}$ & $\mathbf{0}$ & $\mathbf{0}$ & $2 \cdot 3$ & 0 & $\mathbf{2 \cdot 5}$ & $\mathbf{2} \cdot \mathbf{3}$ & $1 \cdot 8$ \\
\hline A. rancens (15) & 0.5 & $\mathbf{0}$ & $\mathbf{0}$ & $\mathbf{0}$ & $\mathbf{0}$ & $\mathbf{0}$ & $\mathbf{0}$ & $\mathbf{0} \cdot \mathbf{1}$ & $\mathbf{0 \cdot 2}$ & $\mathbf{2 \cdot 2}$ & $\mathbf{0}$ & $2 \cdot 5$ & $>1.6$ & $>0.65$ \\
\hline A. lovaniensis (13) & $0 \cdot 5$ & $\mathbf{0}$ & $\mathbf{0}$ & $\mathbf{0}$ & $\mathbf{0}$ & $\mathbf{0}$ & $0 \cdot 46$ & 0.5 & 0.5 & 2 & 0 & $>1 \cdot 96$ & $>1.4$ & $>0.5$ \\
\hline A. ascendens (4937) & $1 \cdot 0$ & $\mathbf{0}$ & $\mathbf{0}$ & 0 & $\mathbf{0}$ & 0 & 0 & 0 & $\mathbf{0}$ & $\mathbf{0}$ & 0 & $>1 \cdot 7$ & $2 \cdot 4$ & $>1 \cdot 2$ \\
\hline A. vini acetati (4939) & $1 \cdot 4$ & $\mathbf{0}$ & $\mathbf{0}$ & $\mathbf{0}$ & $\mathbf{0}$ & $\mathbf{0}$ & $>0.2$ & $>0.3$ & $>0 \cdot 3$ & $>0.3$ & 0 & $>\mathbf{2 \cdot 2}$ & $2 \cdot 4$ & $1 \cdot 8$ \\
\hline A. estunensis (E) & $1 \cdot 2$ & $>0 \cdot 3$ & $\mathbf{0}$ & $\mathbf{0}$ & $\mathbf{0}$ & $\mathbf{0}$ & $>0.3$ & $0 \cdot 4$ & 0.5 & $\mathbf{2} \cdot \mathbf{2}$ & $\mathbf{0}$ & $\mathbf{2} \cdot \mathbf{3}$ & $2 \cdot 35$ & 1.85 \\
\hline A. turbidans (6424) & $\mathbf{2 \cdot 3}$ & $>1 \cdot 6$ & $\mathbf{0}$ & $\mathbf{0}$ & 0 & 0 & $\mathbf{0}$ & 0.4 & $0 \cdot 3$ & $\mathbf{2 \cdot 3}$ & $\mathbf{0}$ & $2 \cdot 5$ & $2 \cdot 8$ & $2 \cdot 0$ \\
\hline A. mobilis (64.28) & $\mathbf{2 \cdot 0}$ & $>0 \cdot 8$ & $\mathbf{0}$ & $\mathbf{0}$ & $>0.5$ & $0 \cdot 2$ & $0 \cdot 2$ & $0 \cdot 6$ & $0 \cdot 4$ & $\mathbf{2 \cdot 5}$ & $\mathbf{0}$ & $\mathbf{2} \cdot \mathbf{5}$ & $2 \cdot 4$ & $>1.8$ \\
\hline \multicolumn{15}{|c|}{ Mesoxydans group (14 strains investigated) } \\
\hline A. aceti (8554) & $\mathbf{1 . 8}$ & $0 \cdot \mathbf{2}$ & $\mathbf{0}$ & $\mathbf{0}$ & $>1 \cdot 4$ & $>0 \cdot 3$ & $\mathbf{0 \cdot 5}$ & 0.5 & $0 \cdot 5$ & $\mathbf{2 \cdot 5}$ & $>0 \cdot 7$ & $\mathbf{2 \cdot 7}$ & $\mathbf{2 \cdot 2}$ & $\mathbf{1 . 9}$ \\
\hline A. mesoxydans (8622) & $>\mathbf{3 . 0}$ & $>\mathbf{2} \cdot \mathbf{1}$ & $\mathbf{0}$ & $\mathbf{0}$ & $0 \cdot 2$ & 0 & $0 \cdot 4$ & 0.5 & $0 \cdot 4$ & $2 \cdot 5$ & $\mathbf{0} \cdot \mathbf{3}$ & $\mathbf{2} \cdot \mathbf{1}$ & $2 \cdot 4$ & $>1 \cdot 7$ \\
\hline A. mesoxydans (4) & $4 \cdot 9$ & $4 \cdot 4$ & $>3 \cdot 1$ & $>\mathbf{3 \cdot 4}$ & $>1 \cdot 3$ & $>1 \cdot 1$ & $0 \cdot 4$ & $0 \cdot 6$ & 0.5 & $2 \cdot 7$ & $>1 \cdot 2$ & $2 \cdot 9$ & $>1 \cdot 7$ & $>0 \cdot 7$ \\
\hline A. xylinum (8747) & $>\mathbf{3 . 5}$ & $>\mathbf{3} \cdot \mathbf{3}$ & $0 \cdot 6$ & $>0.4$ & $>\mathbf{3 \cdot 3}$ & $>1.7$ & $0 \cdot 4$ & $0 \cdot 4$ & 0.5 & $>2 \cdot 1$ & $>0.8$ & $>\mathbf{2} \cdot \mathbf{1}$ & $>\mathbf{2} \cdot 0$ & $>1 \cdot 1$ \\
\hline \multicolumn{15}{|c|}{ Suboxydans group (Gluconobacter) (9 strains investigated) } \\
\hline G. capsulatus (4943) & $1 \cdot 4$ & $\mathbf{0}$ & $\mathbf{0}$ & 0 & $>1.9$ & $\mathbf{0}$ & 0.5 & $0 \cdot 5$ & 0.5 & $0 \cdot 9$ & $0 \cdot 5$ & $\mathbf{0 \cdot 2 3}$ & 0.9 & $\mathbf{0}$ \\
\hline G. suboxydans (26) & $\mathbf{3} \cdot \mathbf{1}$ & $2 \cdot 5$ & $\mathbf{0}$ & $0 \cdot 1$ & $4 \cdot 3$ & $>1.7$ & $0 \cdot 6$ & 0.5 & $0 \cdot 5$ & $1 \cdot 7$ & $>1 \cdot 1$ & $1 \cdot 0$ & 0.8 & $\mathbf{0}$ \\
\hline G. melanogenus (8086) & $\mathbf{2} \cdot \mathbf{2}$ & $1 \cdot 3$ & 0.5 & $\mathbf{0}$ & $4 \cdot 8$ & $4 \cdot 4$ & 0.5 & 0.5 & $0 \cdot 5$ & $>1 \cdot 6$ & $0 \cdot 6$ & $0 \cdot 7$ & 0.8 & $\mathbf{0}$ \\
\hline G. cerinus (21) & 4.5 & $4 \cdot 0$ & $0 \cdot 3$ & $>1.5$ & $3 \cdot 5$ & $1 \cdot 0$ & $\mathbf{0 \cdot 3}$ & 0.9 & 0.9 & $\mathbf{2 \cdot 9}$ & $\mathbf{2 \cdot 2}$ & $\mathbf{3 \cdot 0}$ & $2 \cdot 6$ & $\mathbf{0}$ \\
\hline G. liquefaciens (20) & $\mathbf{2 \cdot 2}$ & $1 \cdot 1$ & 0.5 & $\mathbf{2 \cdot 6}$ & $>2.4$ & $1 \cdot 8$ & $0 \cdot 6$ & $>1 \cdot 0$ & 0.7 & $\mathbf{2} \cdot 35$ & 0.5 & $\mathbf{1} \cdot \mathbf{9}$ & 1.9 & $1 \cdot 4$ \\
\hline
\end{tabular}


Use of the generic name Gluconobacter. There is convincing evidence in the literature that the acetic acid bacteria can be divided into two distinct groups: (i) the peritrichously flagellate or non-flagellate bacteria of similar physiology, named Acetobacter, as redefined by Leifson (1954); (ii) the polarly flagellate or nonflagellate strains of similar physiology for which either the name Gluconobacter Asai or Acetomonas Leifson amended Shimwell are used. Asai $(1934,1935)$ realized for the first time the sharp distinction within the acetic acid bacteria and gave generic rank to two groups, Acetobacter and Gluconobacter, based on several physiological properties. These results were considerably extended by Asai \& Shoda (1958). Twenty years after Asai's first papers Leifson (1954) rediscovered the duality of these bacteria from his studies of the type of flagellation and proposed a new genus Acetomonas for the polarly flagellate strains which oxidized neither lactate nor acetate. This genus was studied and reviewed by Shimwell \& Carr (1959). These genera, Gluconobacter and Acetomonas, are almost identical and a slight redefinition of the former would suffice to make the latter superfluous. Asai (1934, 1935) and Asai \& Shoda (1958) included several strains into Gluconobacter which did not oxidize ethanol to acetic acid and were possibly pseudomonads. The exact position of the acetate-oxidizing Gluconobacter species has not yet been settled. According to Asai \& Shoda (1958) both $G$. liquefaciens and $G$. melanogenus are polarly flagellate. According to Shimwell \& Carr (1959) G. melanogenus had sparse peritrichous flagella, and Stouthamer (1960) published a not very convincing picture of a supposedly peritrichous $G$. liquefaciens. Pending further investigations, we accept Asai's view. On the evidence of our results about the gradual change in the enzymic make-up within the cluster of strains (see below), it would not seem very probable that an abrupt distinction between polarly and peritrichously flagellate strains would exist. One can expect a gradual transition from one type into the other, where it might often be hard to make an impartial decision. For historical reasons we prefer to use the name Gluconobacter with the redefinition as given by Asai \& Shoda (1958), but excluding the strains which are unable to oxidize ethanol to acetic acid.

The oxidative properties of the groups according to Frateur's classification. Frateur's system and nomenclature was built up on the physiological properties of intact organisms. Unfortunately it is a general belief that acetic acid bacteria and in particular those of the oxydans group, possess strongly oxidative properties whereby they oxidize their substrates nearly to completion. This was supposed to be the reason why ketogluconates, fructose, sorbose, dihydroxyacetone, etc. did not accumulate as intermediates from their respective starting compounds. We may quote, for example, Bernauer (1940): 'So sehen wir z.B. bei den Essigbakteriën, dasz manche derselben (wie $A$. rancens) nur in geringe Masse primäre Abbauprodukte anhaüfen. Diese Bakteriënart hat ein sehr starkes Oxydationsvermögen und baut in der Regel gleich bis $\mathrm{zu} \mathrm{CO}_{2}$ ab'. Also Frateur (1950, p. 307) says: 'Le groupe oxydans est caractérisé par un pouvoir oxydatif très brutal. Ses représentants sont capables d'oxyder complètement, jusqu'au stade $\mathrm{CO}_{2}$ et $\mathrm{H}_{2} \mathrm{O}$, une grande quantité de substrats organiques'. Table 3 shows that, quite opposite to expectation, the bacteria from the oxydans group had very poor oxidizing capacities which were nearly comparable to the representatives from the peroxydans group. On the 
other hand, the mesoxydans group, which, as the name indicates, was supposed to occupy a position between the oxydans and the suboxydans group, exhibited the greatest diversity of oxidative abilities. The bacteria from the suboxydans group occupied a separate position, since most of them lacked the Krebs cycle. Neverthe-

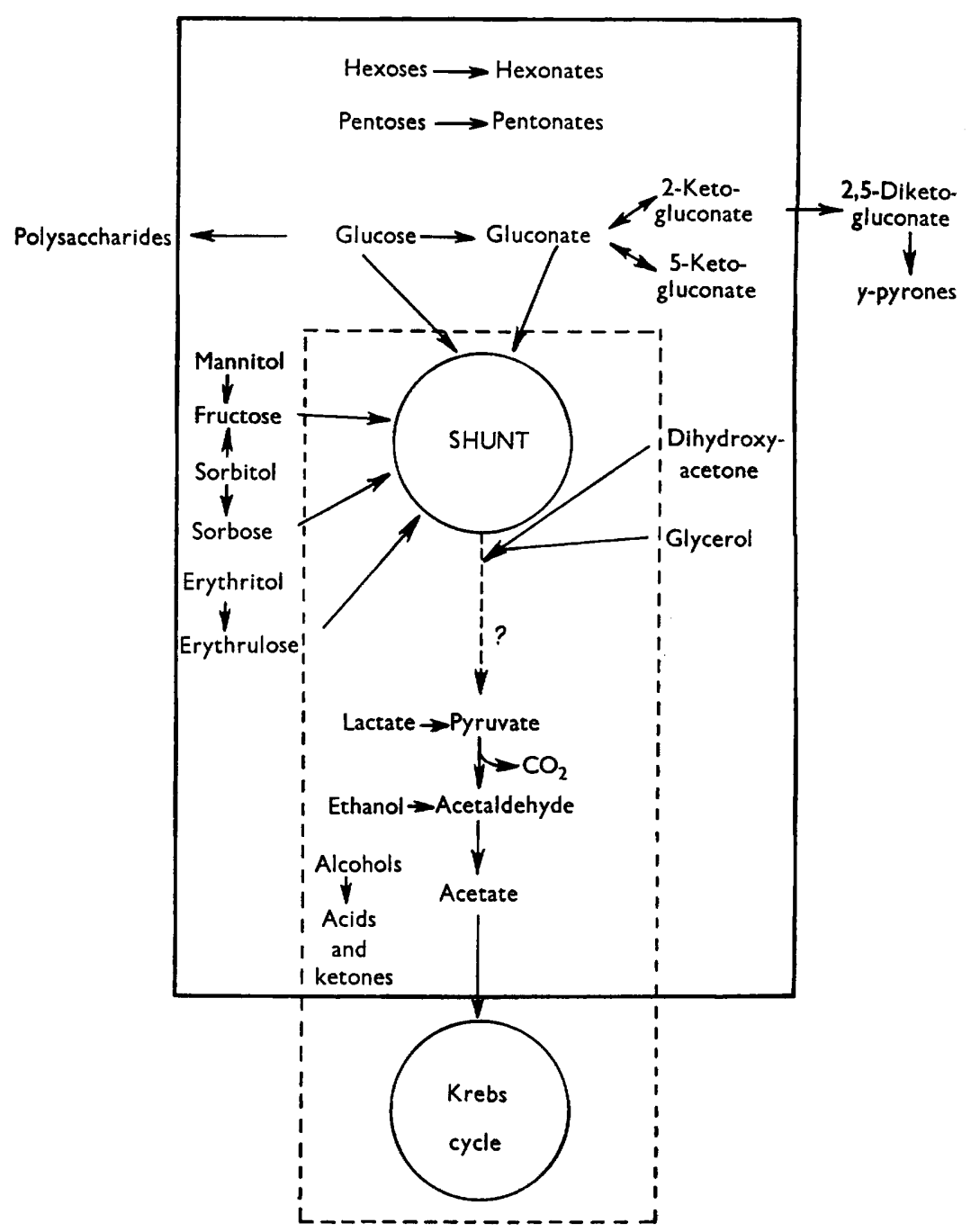

Fig. 2. Simplified metabolic map of the acetic acid bacteria. The overall picture represents the main part of the metabolism of Gluconobacter liquefaciens. Although the latter strain is not known to make polysaccharides, this property was included because it is common to many strains. Two typical extreme divergencies are $G$. suboxydans (metabolic map within the full lines) and Acetobacter peroxydans (broken lines).

less, they oxidized nearly the same range of substrates as the mesoxydans group, and they did it to the same extent. These results agree on the whole with the reports of Stouthamer (1959, 1960). Previously it was shown (De Ley, 1958) that strains of the peroxydans group can oxidize only a few substrates. It can thus be 
seen that the nomenclature of the four groups according to Frateur (1950) becomes misleading in view of the better knowledge of the enzymic constitution of the different organisms.

Comparative carbohydrate biochemistry of the acetic acid bacteria. The oxidative behaviour of resting bacteria represents only the overall activity of the enzyme systems which have been studied in previous papers. The core of their intermediary carbon catabolism appears to consist of three essential parts: (i) Hauge, King \& Cheldelin (1955), Kitos et al. (1958) and Gromet, Schramm \& Hestrin (1957) showed the presence of the hexose monophosphate oxidative cycle in Gluconobacter suboxydans and Acetobacter xylinum. Unpublished work in our laboratory with many other strains has confirmed these results. Stouthamer (1960) detected the same mechanism in $G$. liquefaciens. (ii) The presence of the Krebs cycle enzymes was detected in A. pasteurianus (King, Kawasake \& Cheldelin, 1956), in A. aceti (Rao, 1955) and in G. liquefaciens (Stouthamer, 1960). It seems likely that this mechanism is present in all the acetic acid bacteria, except for the strains of Gluconobacter which are unable to oxidize acetate (see, however, G. cerinus, above). Rao (1955) found indeed that $G$. suboxydans showed only a few steps of this cycle. (iii) Lactate and ethanol are oxidized to acetate by two pathways; one is effected by a set of oxidosome-linked enzymes (De Ley, 1960) and the other by soluble enzymes. This enzymic mechanism was extensively studied in $A$. peroxydans (De Ley \& Schell, $1959 a$ ) and in many other strains (Schell, 1960). Species differentiation is mainly based on the carbohydrate metabolism of the strains (e.g. polysaccharide formation, ketogenic properties, glucose oxidation, etc.). The enzymic explanation of these differences shows that it is very often only a matter of one or at most a few enzymes, located in the outer regions of the metabolic map (Fig. 2).

The natural relationship of the acetic acid bacteria and a proposal for their phylogeny. As pointed out in the introduction, the ideal approach to the rational classification of bacteria consists in giving equal weight to all the properties exhibited by the strains. Many of these properties are an outward reflexion of the inner enzymic anatomy of the organism and in several cases they represent the truth as little as the shadow of an object tells about the object itself. Within one group of closely related bacteria one can considerably limit the number of properties to be studied, analyse their diverse physiological and biochemical behaviour in terms of their enzymic constitution and compare afterwards their metabolic maps. The comparative biochemical approach might apparently give better results in constructing a natural relationship of bacteria and lead to a model of their phylogeny. The former objective is within reach, because it is a description of an existing situation; the latter objective (phylogeny) can be little more than an hypothesis, because it suggests changes in the course of time, deduced from the present-day state. It may be impossible to construct a complete phylogenetic tree for bacteria from the beginning, because of the great time period involved in their evolution, their short generation time, the enormous possibilities for mutation and because of the lack of evidence of comparative morphology and anatomy, embryology and palaeontology, which have been imperative for our knowledge of the evolution of higher organisms. We can at best hope that the knowledge of the comparative biochemistry of existing bacteria might help to elucidate the latest stages in their evolution. Modern trends in biology allow speculation through the concept of 'regressive 
evolution'. It is now a generally accepted belief that the most recent stages in the evolution of many higher organisms consist mostly in gradual loss of properties. On the biochemical level there are several examples of consecutive losses of enzymes, accompanying further stages in evolution (Florkin, 1944). The same trend exists in microbiology. For example, Braun (1953) mentioned several possibilities of a regressive physiological evolution in micro-organisms, the most clear-cut being the commonly occurring mutation from prototrophy to auxotrophy and the transition coliform organisms $\rightarrow$ typhoid bacilli $\rightarrow$ dysentery bacilli, involving successive losses

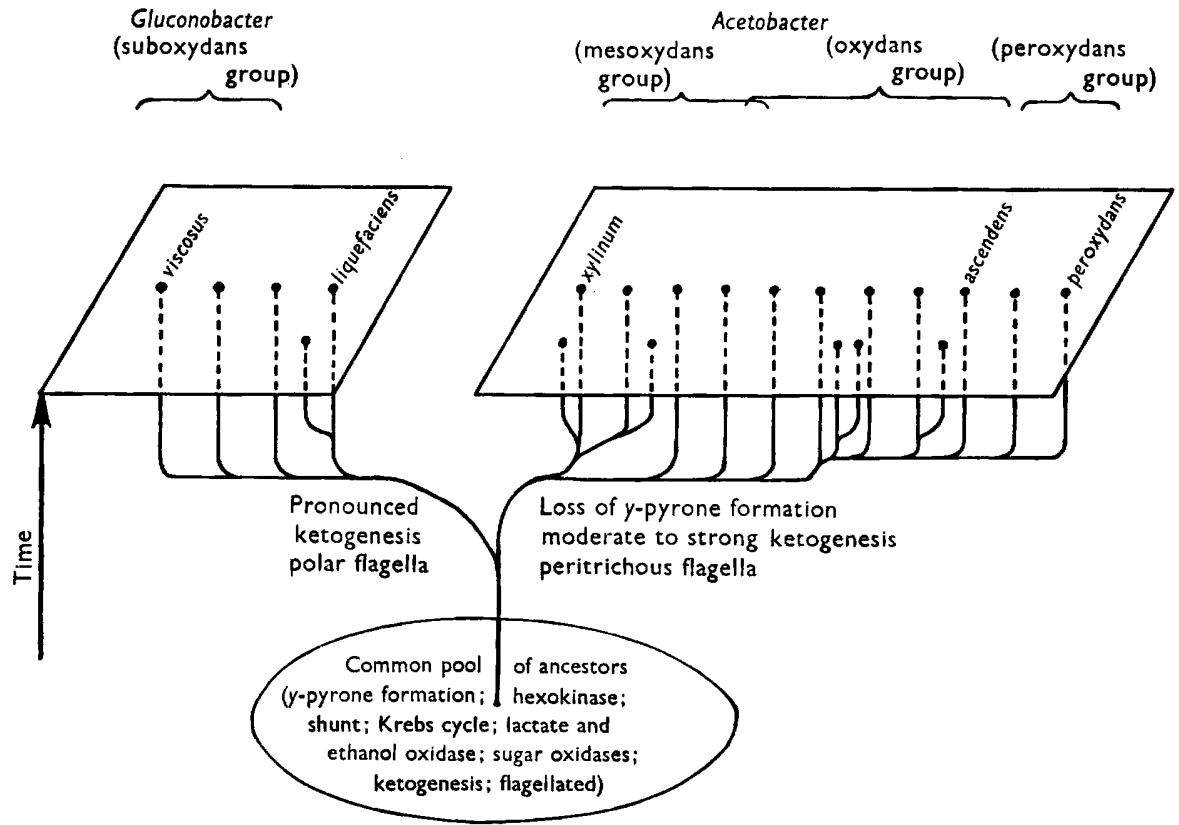

Fig. 3. Possible origin of the acetic acid bacteria from our collection, based mainly on comparative carbohydrate metabolism. For details see Fig. 4 and 5.

of fermentative and biosynthetic steps. A bacterial classification constructed in accordance with this concept, in which the strains of a genus are arranged in a sequence of decreasing capacities, might come closest to representing a phylogenetic relationship. This principle is used in Table 3. From there it is a small step to the hypothesis of phylogenetic lines represented in Figs. 3-5. The genera Acetobacter and Gluconobacter have many features in common, such as the enzymic mechanism of the oxidation of $\mathrm{D}$-lactate and ethanol to acetate, the enzymes of the hexose monophosphate oxidative cycle, but in particular the oxidosome-linked nature of hexose and pentose oxidation, the formation of 2-ketogluconate, the ketogenic characteristics (glycerol to dihydroxyacetone, mannitol to fructose, sorbitol to sorbose, gluconate to 5-ketogluconate, etc.), their acid resistance, etc., that little doubt can remain about their close phylogenetic relationship. In fact many of the quoted properties are so typical for the acetic acid bacteria that they are not encountered in other bacteria, except sometimes in Pseudomonas. One can imagine that both genera evolved from the same pool of ancestors as shown in Fig. 3. In 
spite of the present uncertainty on the exact position of the acetate-oxidizing Gluconobacter species it is clear, according to the above concept, that these strains would be the closest representatives of the ancestral pool of the acetic acid bacteria. From those, or closely related strains, might have evolved in the course of time the presently existing acetic acid bacteria. The relationship between the strains which we studied is represented in Figs. 4 and 5. Both figures represent only some of the 45 strains actually investigated. If a much larger collection had been used, or all the known strains had been included, a much more ramified picture might have emerged.

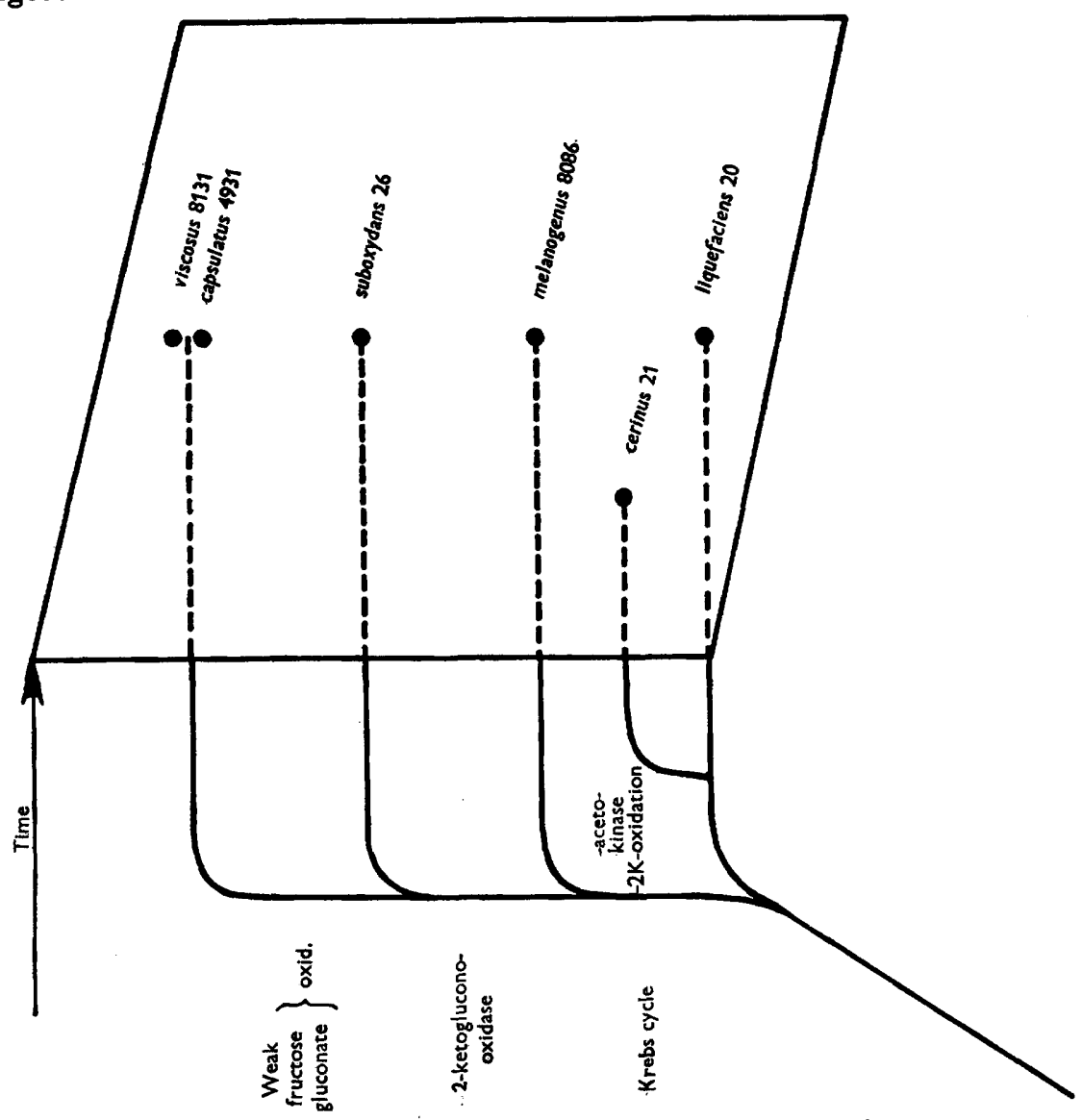

Fig. 4. Details of the scheme in Fig. 8. The Gluconobacter biotype.

The value of the 'species' concept in the acetic acid bacteria. A considerable number of 'species' of acetic acid bacteria have been described. Frateur simplified the situation by relegating closely related varieties to ten main species. Shimwell (1959) and Shimwell \& Carr (1959) followed this attitude to an extreme and established only one species, Acetomonas oxydans, for the suboxydans group of Frateur and no type species at all in the genus Acetobacter. The use of species names implies that each 'species' is characterized by a number of typical and specific morphological and physiological differences, which set them apart from all the others. Our experience with these bacteria (see Figs. 4 and 5 ) shows that there are no such 
abrupt changes in the sequence of strains and that, in each phylogenetic line, they can be arranged in a smooth gradation from the most complex one to the one with the poorest enzymic equipment (from Gluconobacter liquefaciens to G. viscosus and from Acetobacter xylinum to $A$. peroxydans). The differences between a strain and its two immediate neighbours consists at most in one or a few enzymes. With this in

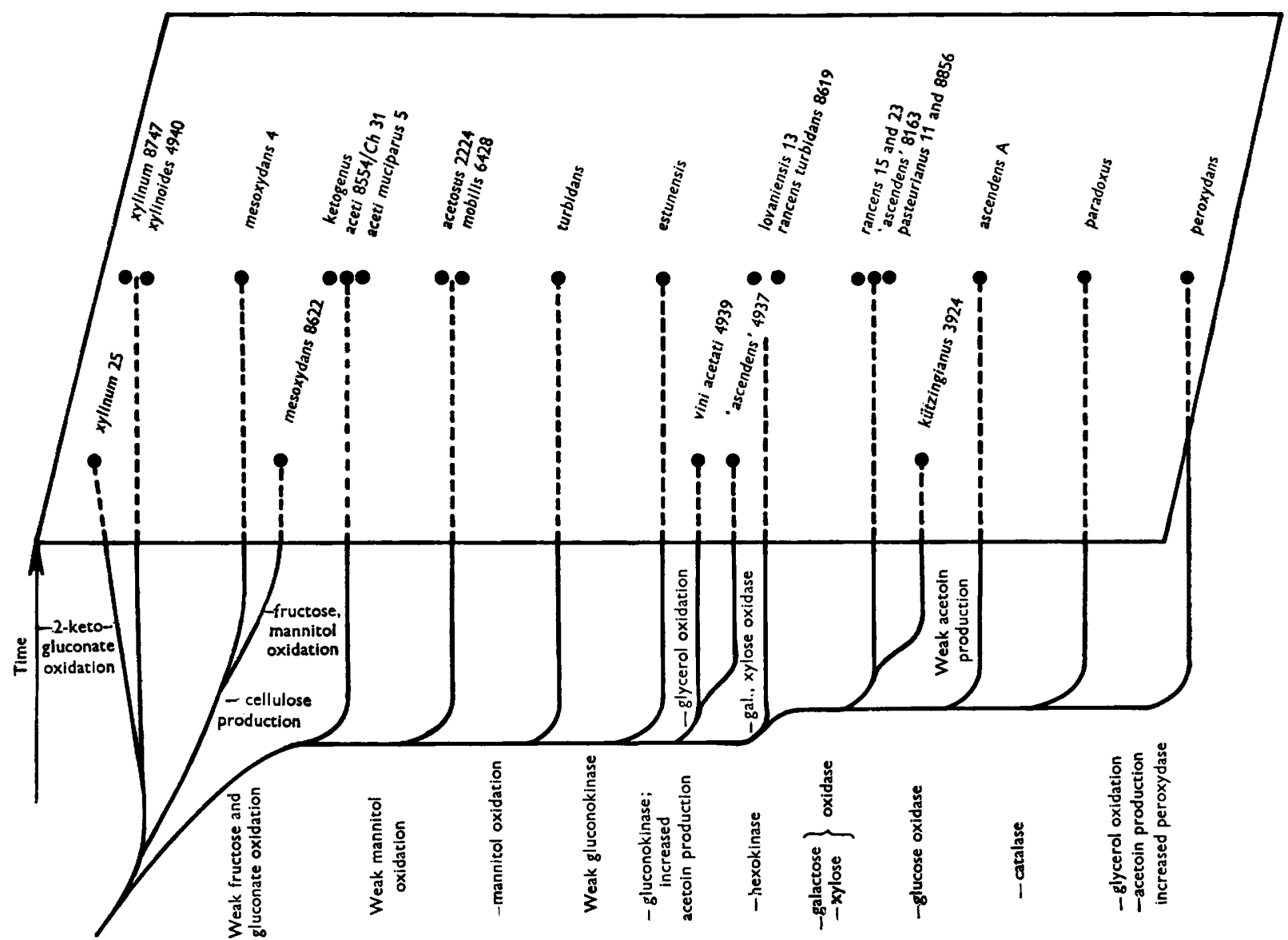

Fig. 5. Detail of the scheme in Fig. 3. The Acetobacter biotype. The property to make polysaccharides was not taken into account, since it is a characteristic easily lost and gained by adaptation and mutation.

mind, it is hard to see where to draw the line in this gradation of properties for defining the limits of a 'species'. The most logical attitude would be to regard the entire cluster of strains (a 'biotype' according to Winogradsky, 1952) from each phylogenetic line as variations of one species and to drop their species names altogether. For sake of clarity and also for historical reasons we shall call the two biotypes Acetobacter aceti (Beijerinck, 1898) Beijerinck, 1900, and Gluconobacter oxydans (Henneberg) comb.nov. There is apparently one practical disadvantage to this new proposal. This is that within each biotype a considerable variety is encountered: compare, for example, $A$. xylinum and $A$. peroxydans, each being at a different end of the line and yet making part of the same biotype. Yet each strain 
requires a label for recognition, whether it be a name or a number. For the sake of clarity and for historical reasons the strains could be labelled as, for example, $A$. aceti (peroxydans), $A$. aceti (xylinum), Gluconobacter oxydans (melanogenum), etc., much as our strains now bear a collection number. The previous species names would then be degraded merely to catalogue numbers and indicate a set of enzymic properties. The characteristics for new and unknown strains could be determined according to the criteria of Frateur, flagella staining (possibly electron microscopy) and the Warburg apparatus $\left(\mathrm{O}_{2}\right.$ uptake $)$ criteria as in the present paper. The creation of new species names should be discouraged in the future, at least when the new strains are closely related to those already existing.

It might appear that our proposal to abolish species names for the acetic acid bacteria and to substitute two names of biotypes, is merely a confirmation of the conclusions of Shimwell (1959) and Shimwell \& Carr (1959). In fact, the proposals are fundamentally different and the conclusions were reached on entirely different grounds. According to Shimwell, the acetic acid bacteria are 'overwhelmingly' unstable, each species mutating spontaneously into another in the laboratory. With such changing properties classification would be impossible; stable strains would not exist. This is contrary to our experience with these bacteria; most of our strains showed unchanged sets of properties over a period of three years. We can thus not accept Shimwell's view of the abnormally high mutability of acetic acid bacteria. Frateur (1950 and personal communication) also emphasized the stability of his strains. Undoubtedly, several authors, including ourselves, have observed spontaneous mutations in this group (but probably not more frequently than with other bacteria). A direct enzymic analysis of the spontaneous change of Gluconobacter melanogenus into G. suboxydans (De Ley \& Stouthamer, 1959) showed that at most two enzymes only were affected. The enzymic interpretation of the 'polysaccharideless' mutants (Acetobacter xylinum to $A$. mesoxydans and $A$. pasteurianus to $A$. rancens) as well as of the other results of Shimwell leads to the same conclusion. The change in the enzymic constitution of the mutants is really never so dramatic as might appear from the papers from Shimwell. A further study of the eventual genetic homogeneity of both biotypes by means of mutations, transformations and recombinations is in progress in our laboratory.

We are greatly indebted to the Nationaal Fonds voor Wetenschappelijk Onderzoek and to the Sigma Xi RESA Research Fund for grants, and to Miss D. Lesaffre for skilful technical assistance.

\section{REFERENCES}

Adanson, M. (1763). Famille des plantes, vol. 1, préface, pp. 154, 163. Paris: Vincent.

Arcus, A. C. \& Edson, N. L. (1956). Polyol dehydrogenases. 2. The polyol dehydrogenases of Acetobacter suboxydans and Candida utilis. Biochem. J. 64, 385.

Asar, T. (1934). Taxonomic studies of acetic acid bacteria and allied oxidative bacteria in fruits and a new classification of oxidative bacteria. J. agric. chem. Soc., Japan, 10, 621, 731, 932, 1124. (In Japanese.)

AsaI, T. (1935). Taxonomic studies of acetic acid bacteria and allied oxidative bacteria in fruits and a new classification of oxidative bacteria. J. agric. chem. Soc., Japan, 11, 50, 331, 377, 499, 610, 674. (In Japanese.)

Asai, T. \& Shoda, K. (1958). The taxonomy of Acetobacter and allied oxidative bacteria. J. gen. appl. Microbiol. 4, 289. 


\section{Metabolism of acetic acid bacteria}

Bergey's Manual of Determinative Bacteriology (1957), 7th ed. Ed. by R. S. Breed, E. G. D. Murray and N. R. Smith. Baltimore, U.S.A.: The William and Wilkins Co.

Bernhauer, K. (1940). Oxydative Gärungen, in Ed. Handbuch der Enzymologie (Nord, F. F. \& Weidenhagen, R.), 2, 1037. Leipzig: Akad. Verlagsgesellschaft.

Bertho, A. (1932). Die Essiggärung. Ergebn. Enzymforsch. 1, 231.

Braun, W. (1953). Bacterial Genetics. London: W. B. Saunders.

Cozıc, M. (1933). Étude biochimique de Bacterium xylinum. Thèse, Bordeaux.

DE LEY, J. (1954). 2-Ketogluconate-6-phosphate, a new intermediate in the carbohydrate metabolism of Aerobacter cloacae. Enzymologia, 17, 55.

De LEY, J. (1958a). Studies on the metabolism of Acetobacter peroxydans. Part I. General properties and taxonomic position of the species. Antonie van Leeurvenhoek J. Microbiol. Serol. 24, 281.

DE LEY, J. (1958b). Pathways of 5-ketogluconate catabolism in bacteria. Biochim. Biophys. Acta, 27, 652.

DE LEY, J. (1959). On the formation of acetoin by Acetobacter. J. gen. Microbiol. 21, 852.

DE LEY, J. (1960). Oxidosomes in bacterial anatomy. Nature, Lond. 188, 331.

De LEY, J. \& Defloor, J. (1959). 2-Ketogluconoreduktase in micro-organisms. Biochim. Biophys. Acta, 33, 47.

De LeY, J. \& Dochy, R. (1960a). Over de Lokalisatie van Fermenten in 'protoplasten' van Azijnzuurbakteriën. Arch. int. Physiol. 68, 215.

De Ley, J. \& Dochy, R. (1960b). On the localisation of oxidase systems in Acetobacter cells. Biochim. Biophys. Acta, 40, 277.

De Ley, J. \& Schell, J. (1959a). Studies on the metabolism of Acetobacter peroxydans. Part II. The enzymic mechanism of lactate metabolism. Biochim. Biophys. Acta, 25, 154.

De Ley, J. \& Scheld, J. (1959b). The oxidation of several substrates by Acetobacter aceti. J. Bact. 77, 445.

De Ley, J. \& Stouthamer, A. H. (1959). The mechanism and localisation of hexonate decomposition by Acetobacter suboxydans and A. melanogenum. Biochim. Biophys. Acta, 34, 171.

DE LEY, J. \& Verhofstede, S. (1957). The place of 2-keto-D-gluconate-6-phosphate in carbohydrate metabolism. Enzymologia, 18, 47.

Florkin, M. (1944). L'évolution biochimique. Liège: Ed. Desoer.

Frateur, J. (1950). Essai sur la systématique des Acétobacters. Cellule, 53, 287.

Frateur, J., Simonart, P. \& Coulon, T. (1954). Études chromatographiques de cultures d'Acétobacter. Antonie van Leeurvenhoek J. Microbiol. Serol. 20, 111.

Gromet, Z., Schramm, M. \& Hestrin, S. (1957). Synthesis of cellulose by Acetobacter xylinum. 4. Enzyme systems present in a crude extract of glucose grown cells. Biochem. J. 67, 679.

Hauge, J. G., King, T. E. \& Cheldelin, V. H. (1955). Oxidation of dihydroxyacetone via the pentose cycle in Acetobacter suboxydans. J. biol. Chem. 214, 11.

Henneberg, W. (1898). Bacterium industrium and B. ascendens. Dtsch. Essigindustr. 2, 145.

Henneberg, W. (1909). Gärungsbakteriologisches Praktikum. Berlin: Ed. Parey.

Hermann, S. \& Neuschul, P. (1931). Zur Biochemie der Essigbakterien. Zugleich ein Vorschlag für eine neue Systematik. Biochem. Z. 233, 129.

King, T. E., Kawasaki, E. H. \& Cheldelin, V. H. (1956). Tricarboxylic acid cycle in Acetobacter pasteurianum. J. Bact. 72, 418.

Kitos, P. A., Wang, C. H., Mohler, B. A., King, T. E. \& Cheldelin, V. H. (1958). Glucose and gluconate dissimilation in Acetobacter suboxydans. J. biol. Chem. 233, 1295.

KLuYver, A. J. (1914). Biochemische Suikerbepalingen. Thesis, Delft.

Kondo, K. \& Ameyama, M. (1958). Carbohydrate metabolism for various Acetobacter species. I. Oxidative activity for various carbohydrates. Bull. agric. chem. Soc., Japan, 22, 369.

LAFAR, F. (1914). Die Essigsäuregärung. Der Abbau einiger organischer Säuren durch Spaltpilze. Handbuch der Technischen Mykologie, 5, 539. Jena: Fischer Verlag. 
LeIfson, E. (1954). The flagellation and taxonomy of species of Acetobacter. Antonie van Leeureenhoek J. Microbiol. Serol. 20, 102.

LXSEnko, O. \& SNEATh, P. H. A. (1959). The use of models in bacterial classification. J. gen. Microbiol. 20, 284.

Neuberg, C. \& Simon, E. (1928a). Alkoholische Zuckerspaltung durch Essigbakterien. Biochem. Z. 197, 259.

Neuberg, C. \& Simon, E. (1928b). Über Verschiedenheit der Vorgänge bei der alkoholischen Zuckerspaltung und der Acetaldehyd-dismutation. Biochem. Z. 199, 232.

NIEL, C. B. vaN (1946). The classification and natural relationships of bacteria. Cold Spring Harb. Symp. quant. Biol. 11, 285.

Niel, C. B. van (1953). Classification and taxonomy of the bacteria and bluegreen algae. In $A$ Century of Progress in the Natural Sciences, 1853-1953, p. 89. New York: Academic Press.

RAO, M. R. R. (1955). Pyruvate and acetate metabolism in Acetobacter aceti and Acetobacter suboxydans. Thesis, Urbana, Illinois, U.S.A.

ScheLL, J. (1960). Vergelijkende biochemische, physiologische und fylogenetische studie van azijnzuurbakteriën. Thesis, Gent.

Shimweld, J. L. (1957). A pattern of evolution in the genus Acetobacter. J. Inst. Brew. 63,45 .

SHimweld, J. L. (1959). A re-assessment of the genus Acetobacter. Antonie van Leeurwenhoels J. Microbiol. Serol. 25, 49.

Shimwell, J. L. \& Carr, J. G. (1959). The genus Acetomonas. Antonie van Leeurwenhoek J. Microbiol. Serol. 25, 353.

Srmon, E. (1930). Utber das zymatische System und die Wirkung der Essigbakterien. Biochem. Z. 224, 253.

Skerman, V. B. D. (1949). A mechanical key for the generic identification of bacteria. Bact. Rev. 13, 175.

SNeAth, P. H. A. (1957a). Some thoughts on bacterial classification. J. gen. Microbiol. $17,184$.

SNeAth, P. H. A. (1957b). The application of computers to taxonomy. J. gen. Microbiol. 17, 201.

Sneath, P. H. A. \& Cowan, S. T. (1958). An electro-taxonomic survey of bacteria. J. gen. Microbiol. 19, 551.

Stouthamer, A. H. (1959). Oxidative possibilities in the catalase positive Acetobacter species. Antonie van Leeurvenhoek J. Microbiol. Serol. 25, 241.

Stouthamer, A. H. (1960). Koolhydraatstofwisseling van de Azijnzuurbacteriën. Thesis, Utrecht.

Thimann, K. V. (1955). The Life of Bacteria, p. 495. New York: MacMillan Co.

Winogradsky, S. (1952). Sur la classification des bactéries. Ann. Inst. Pasteur, 82, 125. 